
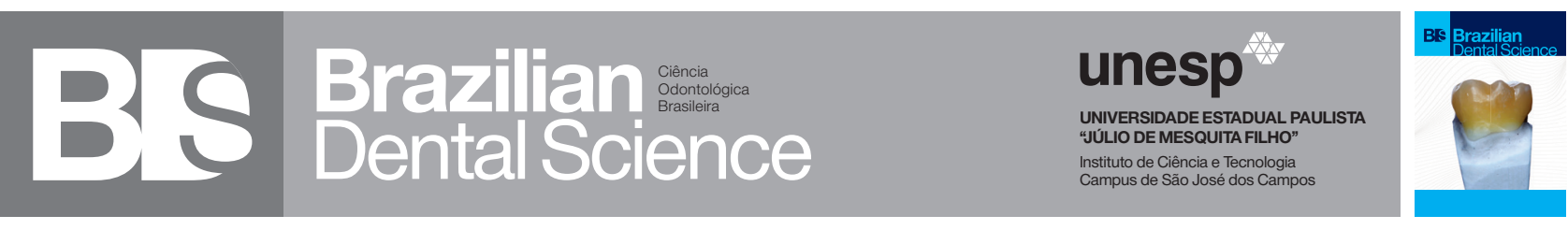

\title{
Relationship between adenoid hypertrophy and sleep apnea in children
}

Relação entre a hipertrofia das adenoides e a apneia do sono em crianças

Ana de Lourdes SÁ DE LIRA ${ }^{1}$, Lucas Paulo de Sousa SILVA ${ }^{1}$

1 - Department of Clinical Dentistry - School of Dentistry of State University of Piauí- Parnaíba- PI - Brazil.

\begin{abstract}
Introduction: It was decided to organize this work on the assumption that it is necessary for all dental surgeons to familiarize themselves with the structure and alterations in oral anatomy from childhood, with attention to the possibility of adenoid hypertrophy (AH) and obstructive sleep apnea syndrome (OSAS) to be present. Objective: to observe in the literature review if the correlation between adenotonsillar hypertrophy and sleep apnea in children was verified and which treatment were adopted. Material and Methods: the following databases were searched: LILACS, MEDLINE, PubMed, Cochrane, Web of Science and SciELO, from January 2014 to August 2018. Results: only 32 articles were included in this literature review because they met all defined inclusion criteria. Conclusion: according the literature, the authors concluded that there is a correlation between hypertrophy of the adenoid glands and apnea of the sleep in children. Hypertrophy presents as the main cause of obstructive sleep apnea syndrome in pediatric patients and its treatment may be surgical, removal of the adenoid, drug or orthodontic.
\end{abstract}

\section{KEYWORDS}

Obstructive sleep apnea; Adenoid hypertrophy; Adenoid glands.

\section{RESUIMO}

Introdução: decidiu-se organizar este trabalho pelo pressuposto de que é necessário todos os cirurgiõesdentistas se familiarizarem com a estrutura e alterações na anatomia oral desde a infância, com atenção à possibilidade da hipertrofia da adenóides (HA) e a síndrome da apnéia obstrutiva do sono(SAOS) estar presente. Objetivo: observar por meio da revisão de literatura se existe correlação entre a hipertrofia das adenoides e apneia do sono em crianças e qual o tratamento adotado. Material e Métodos: foram feitas pesquisas indexadas nas bases de dados: LILACS, MEDLINE, PubMed, Cochrane, Web of Science e SciELO, no período de janeiro de 2014 a agosto de 2018. Resultados: somente 32 pesquisas foram inclusas na revisão de literatura porque estavam de acordo com os critérios de inclusão. Conclusão: de acordo com a literatura, os autores concluíram que há correlação entre a hipertrofia das glândulas adenoides e a apneia do sono em crianças. A hipertrofia se apresenta como a principal causa da síndrome da apneia obstrutiva do sono em pacientes pediátricos e seu tratamento poderá ser cirúrgico, pela remoção das glândulas adenoides, medicamentoso ou ortodôntico.

\section{PALAVRAS-CHAVE}

Apneia obstrutiva do sono; Hipertrofia adenoide; Glândulas adenoides. 


\section{INTRODUCTION}

$\mathrm{O}$ bstructive sleep apnea syndrome (OSAS) is a condition with high prevalence in children involving various morbidities, including neurocognitive, behavioral, cardiovascular and metabolic [1].

It is characterized by a combination of repetitive episodes of prolonged partial airway obstruction (obstructive hypopnea) and / or intermittent collapse (obstructive apnea) $[2,3]$, disturbing normal ventilation patterns during sleep, resulting in interruption of the exchanges (characterized by intermittent hypoxia and hypercapnia). Hypercapnia is the increase of carbon dioxide in the arterial blood that can be caused by alveolar hypoventilation (in case of asphyxia, for example). Tissue hypoxia occurs when the supply of oxygen (O2) to tissues is unable to satisfy cellular demand [4].

The adenoids and tonsils occupy most of the pharyngeal space and are common in children aged 3 to 8 years. In some children, adenotonsillar hypertrophy (ATH) may occur during the preschool years and persist beyond 8 years of age, diverging from unchanged children, in whom adenoids gradually regress after eight years of age [5].

This work was carried out on the assumption that it is necessary for all dental surgeons to familiarize themselves with the structure and alterations in oral anatomy from childhood, with attention to the possibility of ATH and OSAS being present, and these professionals can assist in the orthodontic treatment.

The objective of this literature review was to observe if there is a correlation between adenotonsillar hypertrophy and sleep apnea in children and which treatment was adopted.

\section{METHOD}

Data collection was performed in the following electronic databases: LILACS, MEDLINE, PubMed, Cochrane, Web of
Science and SciELO, from January 2014 to August 2018. The following descriptors were used to search for articles: "Adenotonsillar hypertrophy and obstructive sleep apnea syndrome" and "Adenotonsillar hypertrophy and OSAS", with one or more keywords.

The inclusion criteria that were adopted for selection of national and international scientific productions included published productions that focused on the direct or indirect relation of hypertrophy of the adenoid glands to sleep apnea in children. The exclusion criteria were articles about acute adenotonsillitis, tonsillectomy, rhinitis, asthma, neuromuscular disease and craniofacial abnormalities and duplicate scientific researches.

The bibliographic search resulted initially in 205 articles, which, after applying the inclusion and exclusion criteria, reduced to 78 publications. From this set, after reading the abstracts of the works, there were 49 articles that were read in full, with the intention of contemplating the inclusion criteria. Finally, 32 articles were included in this literature review because they met all defined inclusion criteria.

\section{Anatomical architecture of adenoid hypothydria and sleep apneia}

The polysomnography test is the gold standard for determining the severity of OSAS because oximetry wrongly classifies approximately two-thirds of children with moderate to severe disease in mild OSAS or primary snoring [6].

Polysomnography or polygraphy is indicated in children with symptoms of obstructive sleep disorders and before adenotonsillectomy, especially in the presence of obesity, craniofacial deformities, neuromuscular disorders, complex abnormalities (eg, Chiari malformation, Down's syndrome and Prader-Willi); or when the need for treatment is unclear [7]. 


\begin{abstract}
Rizzi et al. [2] showed that in children with adenotonsillar hypertrophy nasal resistance seems to be risk factor for OSAS and the anterior rhinometry appears as a useful tool in routine evaluation of sleep-disordered breathing in these patients.
\end{abstract}

The study of Valera et al. [5] found that adenotonsillar hypertrophy leads to more severe apnea patterns in preschool-age children. However, the apnea pattern does not differ between isolated adenoid hypertrophy and adenoid hypertrophy associated with tonsil hypertrophy. The authors concluded that OSAS is more severe in younger children with adenotonsillar hypertrophy than in older children, in school-age.

The total volume of the adenoid gland in children with OSAS can reach $11.398 \mathrm{~mm}^{3}$, while in obese without OSAS it reaches 8.429 $\mathrm{mm}^{3}$, in lean, the volume is around 6.464 $\mathrm{m}^{3}$. In a comparison between three girls with different apnea rates per hour (ARH), the first presented an ARH of $0.0 / \mathrm{h}$ and adenoid volume of $4.071 \mathrm{~mm}^{3}$, the second with ARH of 0.3 / ha and $5.564^{3}$ of adenoid volume, while the third, which presented ARH of 9.0 / h (OSAS) contained 14,607 $\mathrm{mm}^{3}$ of adenoid [8].

The prevalence of OSAS in obese children in the general population is high $[9,10]$. However, the degree of obesity (z-score of body mass index - BMI) and the anthropometric predictors of OSAS commonly used in adults (BMI and neck circumference) were not significantly associated [10].

There are no definitive recommendations to culminate in the decision to adenotonsillectomy (AT). There is a relationship between ATH and right ventricular function in children, since the plasma level of NT-proBNP (an inactive peptide) is significantly higher in the group in these children [11].

Sleep architecture in the common phenotype of pediatric OSAS is altered in aspects such as total sleep time, wake - up after sleep onset, sleep latency (minutes), excitation - spontaneous, respiratory and moving index, also interfering with the efficiency of the deep sleep [12].

In children with ATH the detection of respiratory effort during routine polysomnography can be evaluated by monitoring the mandibular position. Changes greater than $0.4 \mathrm{~mm}$ in the mandibular position during the respiratory cycle indicate greater respiratory effort in these children. The mouth opening during respiratory effort is also a reason for limiting respiratory flow [13].

In a scenario where OSAS testing capabilities are rationed or severely limited, a diagnostic approach based on oximetry can help maximize cost savings and help minimize the occurrence of adverse perioperative events, ensuring the implementation of appropriate management strategies in those children with increased risk of respiratory complications [14-18].

Children with OSAS have elevated airway resistance $\left(4.3 \mathrm{~cm} \mathrm{H}_{2} \mathrm{O} / \mathrm{L} / \mathrm{sec}\right)$ that improves after OSAS treatment $(2.8 \mathrm{~cm}$ $\mathrm{H}_{2} \mathrm{O} / \mathrm{L} / \mathrm{sec}$ ). This is due to the overload of the upper airways associated with ATH and may contribute to the increased frequency of respiratory diseases in untreated infant sleep apnea [15]. Findings also confirm that the African-American race and obesity are associated with more severe OSAS in children 5 to 9 years [16].

Góis et al. [19] found that the subscale of respiratory sleep disorders was a useful tool for a diagnostic suspicion of ATH in preschool children. The Sleep Disorders Scale for Children (SDSC) is a validated questionnaire for the Portuguese language that has been increasingly used in studies on respiratory disorders in children and adolescents.

It was first investigated by Bayraktar et al. [18] choroidal blood flow in the pediatric population with OSAS. The choroid is a vascular layer between the sclera and the 
retina. It is one of the most vascularized tissues in humans and, due to OSAS, hypoxia, hypercapnia, impaired balance of endothelial vasoactive substances, hemodynamic changes and autonomic dysfunction, can cause compromised choroidal blood flow. Significantly thinner choroidal thicknesses and nasal choroidal measurements of 1.000 $\mu \mathrm{m}$ and $1.500 \mu \mathrm{m}$ were observed in patients with OSAS due to ATH.

\section{Non surgical treatments of adhesive hosts and hypertrophy}

Topical nasal corticosteroids have been used as effective non-surgical alternatives for the treatment of nasal symptoms related to adenoid hypertrophy. Its administration can significantly improve symptoms of nasal obstruction, but it does not always achieve adequate reduction in adenoid size [19].

In addition to the large tonsils and adenoids, children with OSAS may have narrow upper airways, due to narrow and long faces, maxillary constriction and / or arched high palate, or some degree of mandibular retrusion. However, the correlation between these dentofacial abnormalities and OSAS has been ignored, although in the last decades, correction of mandibular or maxillomandibular anomalies has provided significant improvement in OSAS [20].

Rapid maxillary expansion (RME) may be indicated in cases of respiratory disorders of the upper areas regardless of the degree of obstruction, this because children who present this pathology, in their great totality also present a narrowing of the superior arch, as a consequence of the observed mouth breathing. With the expansion is observed the increase of nasopharyngeal space, facilitating the establishment of nasal breathing. It is valid in cases in which there is no indication of adenotonsillectomy, when patients or caregivers refuse or are prevented from undergoing surgery, or even after surgery when symptoms recur $[20,21]$.
After maxillary expansion in the treatment of obstructive sleep apnea in children, it was found that orthodontic treatment in children with malocclusions is more effective if started as soon as the symptoms of OSAS appear. It has been proved that its presence has a deleterious effect on the treatment outcome of hyperdivergent patients receiving orthodontic treatment. Its diagnosis and early management during childhood may favor the orthodontic treatment of these patients [20].

Cysteine leukotrienes (CysLTs) are a protein that in humans is encoded by the CYSLTR1 gene. When leukotriene release occurs, they interact with the Cysteinyl leukotriene receptor, which results in edema, airway inflammation and bronchoconstriction. Leukotrienes potentially promote ATH in children with OSAS. In children with snoring, it occurs during the preschool years and persists beyond 8 years of age and CysLTs have been implicated in its pathogenesis. Inhibition of leukotriene biosynthetic enzymes should be explored as a potential therapeutic intervention for pediatric OSAS [22].

Two studies have examined the effect of Montelukast sodium (a leukotriene receptor antagonist that blocks these substances) in cases of adenoid hypertrophy associated with sleep apnea. It has been reported that Montelukast in oral chewable tablets, administered over a 12week period in children, effectively alleviated the severity of snoring, sleep discomfort and mouth breathing, as well as reduced adenoid tissue size $[23,24]$.

The topical use of nasal nasal spray for chronic grade 2 and 3 adenoiditis is a safer, simpler and painless alternative to surgery to achieve remission in young children. This is most relevant in developing countries where the burden of disease at younger age is high and often causes coryza and snoring. It may also be useful when surgery is contraindicated in conditions such as hemorrhagic disorders, cleft palate, and bifid uvula [25]. 


\section{Surgical treatment of sleep apneia: pre, post-operative and results}

Children affected by adeno-tonsillar hypertrophy and OSAS do not present a significant delay in growth, but present a deceleration in growth rate, suggesting that the levels and results of growth hormone release are higher after surgery producing accelerated growth [26].

In a study by Pavon et al. [27] children with obstructive sleep apnea who subsequently required adenotonsillectomy presented greater variability in pulse frequency compared to those without surgical indication, and should consider dexmedetomidine or midazolam for children with severe OSAS if necessary preanesthetic medication.

The residual mean obstructive apneahypopnea index, excitation index, and sleep efficiency are generally similar to preoperative indices. Changes in architecture and sleep duration were associated with increased preoperative anesthetic and narcotic doses. The safety of narcotics for analgesia after surgery has been questionable [28].

Digital tools are a potentially useful modality for the clinical evaluation of the mechanical properties of the upper airway after adenotonsillectomy in obese children with OSAS. They could also be a useful tool to simulate outcomes of other surgical approaches in other phenomena of OSAS in children and adults [29].

This surgical procedure may be successful when the upper airway is narrowed only by ATH. However, when a patient has a lower jaw associated with it, the surgery can not lead to a sufficient improvement of OSAS $[30,31]$.

In a research it was proposed that adenotonsillectomy may decrease enuresis and sympathetic nerve activity in children with OSAS [32]. Children affected by ATH and OSAS do not present a significant delay in growth, but present a deceleration in the growth rate. After surgery, growth increased, as demonstrated by increased gain and growth after the three-month postoperative period, probably due to weight gain [33].

This surgical intervention significantly reduces apnea and hypopnea index, cortical excitation index and $\mathrm{O} 2$ desaturation index, and the mandibular motion index decreases to the same extent as the polysomnographybased apnea-hypopnea index. However, the number of episodes of excitation related to respiratory effort does not normalize, which is also reflected by the presence of persistently abnormal mandibular movement pattern [34] .

For children with OSAS, this surgery increases basal respiratory rate during sleep. Normalizing the rate of apnea and hypopnea, spontaneously or through surgery, results in a lower heart rate. As both changes are generally small, their clinical significance is uncertain and may help maintain long-term cardiovascular health [35].

Authors also found significant changes in apnea-hypopnea index, apnea index, minimal O2 saturation and excitation index after with significant changes in most of the symptoms such as: snoring, morning headache, mouth breathing, wheezing during sleep, restless sleep, nasal obstruction and difficulty of awakening in the morning $[34,35]$.

In a study by Lee et al. [7] it was confirmed that immediately after adenotonsillectomy, snoring ceased completely in $25 \%$ of patients and decreased in the remaining $75 \%$ at the beginning of the follow-up period.

Researches that described the study design and correlated ATH with SAOS were mentioned in Table 1. 
Table 1 - Researches that described the study design and correlated ATH with SAOS

\begin{tabular}{|c|c|c|c|c|c|}
\hline Authors & Sample & Study Design & Method & Results & Pvalue \\
\hline $\begin{array}{l}\text { Durdik et } \\
\text { al.[8] }\end{array}$ & $\begin{array}{l}116 \text { children(3-8 years) with ATH and } \\
\text { suspected OSAS; } 51 \text { healthy children } \\
\text { (control group) }\end{array}$ & $\begin{array}{l}\text { prospective } \\
\text { cross-sectional } \\
\text { study }\end{array}$ & $\begin{array}{l}\text { polysomnography } \\
\text { was performed }\end{array}$ & $\begin{array}{l}94 \text { patients ( } 59.60 \% \text { male) showed } \\
\text { phenotype of OSAS }\end{array}$ & $<.01$ \\
\hline $\begin{array}{l}\text { Ignacio et } \\
\text { al.[10] }\end{array}$ & $\begin{array}{c}\text { 31 children (mean age } \pm \mathrm{SD}=9.7 \pm \\
\text { 3.0) with ATH and OSAS; } \\
\text { 31 healthy children(mean age } \pm \mathrm{SD}= \\
10.5 \pm 2.5\end{array}$ & $\begin{array}{l}\text { Case control } \\
\text { study }\end{array}$ & $\begin{array}{l}\text { polysomnography } \\
\text { was performed }\end{array}$ & $\begin{array}{l}\text { ATH } \\
\text { may contribute to the increased fre- } \\
\text { quency of OSAS, with improve after } \\
\text { treatment. }\end{array}$ & $<.01$ \\
\hline $\begin{array}{l}\text { Mitchell et } \\
\text { al. [11] }\end{array}$ & $\begin{array}{c}453 \text { children } 5.0 \text { to } 9.9 \text { years of } \\
\text { age with ATH whowere considered } \\
\text { candidates for AT }\end{array}$ & $\begin{array}{l}\text { Randomized } \\
\text { clinical trial }\end{array}$ & $\begin{array}{l}\text { Polysomnography } \\
\text { for diagnosis of } \\
\text { OSAS. }\end{array}$ & $\begin{array}{l}\text { OSAS severity is influenced } \\
\text { by anatomic factors and abnormal } \\
\text { upper airway neuromuscular tone. }\end{array}$ & $<.01$ \\
\hline $\begin{array}{l}\text { Bayraktar } \\
\text { and Şimşek } \\
\text { [18] }\end{array}$ & $\begin{array}{c}109 \text { pediatric OSAS patients with } \mathrm{ATH} \\
\text { (mean age } \pm \mathrm{SD}=5.4 \pm 0.9 \text { ) and } 42 \\
\text { age-sex matched controls (mean age } \\
\pm \mathrm{SD}=5.2 \pm 0.75\end{array}$ & $\begin{array}{l}\text { Prospective } \\
\text { study }\end{array}$ & $\begin{array}{l}\text { Nasal choroidal } \\
\text { thickness measure- } \\
\text { ments. }\end{array}$ & $\begin{array}{c}\text { Thinner choroidal thicknesses in the } \\
1,000 \mu \text { mand } 1,500 \mu \text { masal choroidal } \\
\text { measurements in patients with OSAS } \\
\text { due to ATH }\end{array}$ & $<.01$ \\
\hline De etal. [23] & $\begin{array}{c}20 \text { obese children between 8-17 years } \\
\text { of age with OSAS and ATH }\end{array}$ & $\begin{array}{l}\text { Prospective } \\
\text { study }\end{array}$ & $\begin{array}{l}\text { polysomnography } \\
\text { was performed } \\
\text { before and after AT }\end{array}$ & $\begin{array}{c}\text { Obese children undergoing AT for OSA } \\
\text { are at increased risk for residual OSA } \\
\text { after surgery. }\end{array}$ & $<.05$ \\
\hline $\begin{array}{l}\text { Martineli et } \\
\text { al. [33] }\end{array}$ & $\begin{array}{c}44 \text { obese children(mean age } \pm \mathrm{SD}= \\
7.6 \pm 2.5 \text { ); } 19 \text { with OSAS and ATH. }\end{array}$ & $\begin{array}{l}\text { Prospective } \\
\text { cohort study }\end{array}$ & $\begin{array}{l}\text { Nasofibrolaryngos- } \\
\text { copy, polysomno- } \\
\text { graphy, and labo- } \\
\text { ratory allergic tests } \\
\text { were performed. }\end{array}$ & $\begin{array}{c}\text { The occurrence rate of OSA in obese } \\
\text { children was high. ATH was the factor } \\
\text { associated with OSA. }\end{array}$ & $<.05$ \\
\hline
\end{tabular}

\section{DISCUSSION}

Schwab et al. [6] and Lee et al. [7] exemplified standard gold exams for OSAS. Polysomnography is classified as a gold standard because oximetry, although it is actually much cheaper and accessible [32], is not 100\% reliable [7]. It is noteworthy the difference in size between adenoid gland volume among obese and lean children, up to triple in size $[8,9,31]$. However, in obese children, the BMI index is not a reliable tool for OSAS diagnosis [9].

There are cardiovascular changes [11] and respiratory efforts [13] in children with ATH. The influence of an inactive peptide on the function of the right ventricle is much greater in children with this pathology [11]. During the night sleep of children there is a respiratory effort detection assessed by the mandibular position. The mouth opening during respiratory effort is one of the reasons for limiting infant breathing [13].

The efficiency of sleep and also of deep sleep presents high resistance of the airways in children with OSAS. This happens precisely because of the overload of the upper airways associated with ATH [15]. Authors such as Bayraktar et al. [18] and Góis et al. [19] emphasized that ATH and falsiform disease are unrelated and choroidal blood flow in the pediatric population was significantly shorter and choroidal nasal measurement higher in patients with OSAS [18].

It should be emphasized that among the 32 studies that investigated and verified the correlation between ATH and OSAS, there are 6 studies $[8,10,11,18,23,33]$ that described the study design, ranging from a case-control study to a randomized control trial (Table 1).

Regarding OSAS non-surgical treatments, some authors exemplify that steroids and nasal corticosteroids are the best options in children with ATH, significantly improving symptoms of nasal obstruction, but without achieving a reduction in adenoid size. It may also be useful when surgery is contraindicated in conditions such as hemorrhagic disorders and cleft palate $[19,22]$. 
The maxillary expansion when performed soon when the symptoms of OSAS appear to be more effective [20,21]. Rapid maxillary expansion is indicated in all cases of respiratory disorders, because it is an auxiliary treatment, but no less important than the adenotonsillectomy itself, regardless of the order in which these two procedures are performed. For these authors, neither the size of the tonsils nor the adenoid, evaluated by nasopharyngoscopy, were able to predict which treatment should be performed first: surgery or orthodontic treatment.

In the question of cysteinyl leukotrienes, which potentially promote ATH, authors have specified that the inhibition of these leukotriene biosynthetic enzymes is a form of effective nonsurgical treatment in sleep apnea. A reduction of $17 \%$ in the volume of adenoid tissue after administration of Montelukast was observed [24].

After clinical evaluation of the mechanical properties of the upper airway after adenotonsillectomy in children [30] it was found massively among the authors that there is a significant improvement in snoring, enuresis and in the behavioral problems of the child and neurocognitive functions [25-35]. The snoring, apnea and hypopnea index, the cortical excitation index and the $\mathrm{O} 2$ desaturation index, and the mandibular movement index are significantly reduced.

\section{CONCLUSION}

The authors concluded that there is a correlation between hypertrophy of the adenoid glands and sleep apnea in children. Hypertrophy presents as the main cause of obstructive sleep apnea syndrome in pediatric patients and its treatment may be surgical, by removal of the adenoid, drug or orthodontic glands, and RME is valid in cases in which there is no indication of adenotonsillectomy, or as auxiliary after its realization.

\section{REFERENCES}

1. Sanchez-Armengol A, Fuentes-Pradera MA, Capote-Gil F, García-DiazE, Cano Gómez S, Carmona-Bernal C, Castillo-Gómez J. Sleeprelated breathing disorders in adolescents aged 12 to 16 years: clinical and polygraphic findings. Chest 2001May;119(5):1393-400.

2. Rizzi M, Onorato J, Andreoli A, Colombo S, Pecis M, Marchisio P, etal. Nasal resistances are useful in identifying children with severe obstructive sleep apnea before polysomnography. Int JPediatr Otorhinolaryngol. 2002 Aug;65(1):7-13. doi:10.1016/S0165-5876(02)00119-2.

3. Sin S, Wootton DM, McDonough JM, Nandalike K, Arens R. Anterior nasal resistance in obese children with obstructive sleep apnea syndrome. Laryngoscope. 2014 Nov;124(11):2640-4.

4. Villa MP,Sujanska A, Vitelli 0, Evangelisti M, Rabasco J, Pietropaoli N, et al. Use of the sleep clinical record in the follow-up of children with obstructive sleep apnea (OSA) after treatment. Sleep Breath. 2016 Mar;20(1):321-9.

5. Valera FCP, Avelino MAG, Pettermann MB, Fujita R, Pignatari SSN, Moreira PS OSAS in children: correlation between endoscopic and polysomnographic findings. Otolaryngology Head Neck Surgery.2005 Feb;132(2):268-72.

6. Schwab RJ, Kim C, Bagchi S, Keenan BT,Comyn F,Wang S, et al. Understanding the Anatomic Basis for Obstructive Sleep Apnea Syndrome in Adolescents. Am JRespir CritCare Med. 2015 Jun 1;191(11):1295-309. doi: 10.1164/ rccm.201501-01690C.

7. Lee JH, Yoon JM, Lim JW,Ko OK, Choi SJ, Kim J, Cheon EJ.Effect of adenotonsillar hypertrophy on right ventricle function in children. Korean J Pediatrics. 2014 Nov;57(11):484-88. doi:10.3345/kjp.2014.57.11.484.

8. Durdik P, Sujanska A, Suroviakova S, Evangelisti M, Banovcin P,Villa MP.Sleep architecture in children with common phenotype of obstructive sleep apnea. $\mathrm{J}$ Clin Sleep Med. 2018 Jan;14(1):9-14.

9. Martinot J-B, Senny F,Denison S, CuthberV, Gueulette E, Guénard H, Pépin JL Mandibular movements identify respiratory effort in pediatric obstructive sleep apnea.J Jlin Sleep Med. 2015 Apr 15;11(5):567-74. doi:10.5664/ jcsm.4706.

10. Ignacio E. Tapia, Carole L. Marcus, Joseph M. McDonough, Ji Young Kim, Mary Anne Cornaglia, Rui Xiao, Julian L. Allen. Airway resistance in children with obstructive sleep apnea syndrome. Sleep. 2016 Apr;39(4):793-99. doi:10.5665/ sleep.5630

11. Mitchell RB, GaretzS, Moore RH, Rosen C,Marcus C, KatzL, etal. The use of clinical parameters to predict obstructive sleep apnea syndrome severity in children: the childhood adenotonsillectomy (CHAT) Study randomized clinical trial. JAMA Otolaryngol Head Neck Surg.2015 Feb;141(2):130-6. doi:10.1001/ jamaoto.2014.3049.

12. Kulekci M, Torun MM, Ipek HD, Ozdemir S, Can G, Develioglu 0, Tokman H Bacteriology of adenoids in children with adenoid hypertrophy despite mometasone furoate administration. Pediatric Infect Dis. 2016;1(30);1-6. doi: 10.21767/2573-0282.100030

13. Villa MP, Rizzoli A, Rabasco J, Vitelli O, Pietropaoli N, Cecili M, Marino A, Malagola C. Rapid maxillary expansion outcomes in treatment of obstructive sleep apnea in children. Sleep Med. 2015 Jun;16(6):709-16. doi:10.1016/j. sleep.2014.11.019.

14. Tsaoussoglou M, Hatzinikolaou S, Baltatzis GE, Lianou L, Maragozidis P, Balatsos N et al. Expression of leukotriene biosynthetic enzymes in tonsillar tissue of children with oobstructive sleep apnea: a prospective nonrandomized study. JAMA Otolaryngol Head Neck Surg. 2014 0ct;140(10):944-50. doi:10.1001/jamaoto.2014.1936 
15. ShokouhiF,Meymaneh Jahromi A, Majidi MR SalehiM. Montelukast in adenoid hypertrophy: its effect on size and symptoms. Iranian Journal of Otorhinolaryngology.2015 Nov;27(83):443-8.

16. Kheirandish-Gozal L, Bandla HP,GozalD. Montelukast for children with obstructive sleep apnea: results of a double-blind, randomized, placebocontrolled trial. Ann Am Thorac Soc. 2016 0ct;13(10):1736-41. doi:10.1513/ AnnalsATS.201606-4320C.

17. Tingting Zhao, Peter Ngan, Fang Hua, Jie Zheng, Shunquan Zhou, Man Zhang, Hui Xiong, and Hong He. Impact of pediatric obstructive sleep apnea on the development of Class II hyperdivergent patients receiving orthodontic treatment: a pilot study. Angle 0rthod. 2018 Sep;88(5):560-6. doi: 10.2319/110617-759.1

18. Bayraktar C, Şimşek A. Evaluation of choroidal thickness measurements in pediatric obstructive sleep apnea syndrome patients. Turk J Pediatr. 2017; 59(1):62-7.

19. Góis CRT de, D’Ávila JS, CipolottiR, Lira AS, Silva ALL. Adenotonsillar hypertrophy in pre-school children with sickle cell disease and diagnostic accuracy of the sleep disturbance scale for children. International Archives of Otorhinolaryngology. 2018 Jan;22(1):55-9. doi:10.1055/s-0037-1602702.

20. Villa MP,Malagnola C, Pagani J, Montesano M, Rizzoli A, Guilleminault C. Rapid maxillary expansion in children with obstructive sleep apnea syndrome: 12 months follow-up. Sleep Med. 2007 Mar;8(2):128-34.

21. GuilleminaultC, Quo S, Huynh NT,LiK. Orthodontic expansion treatment and adenotonsillectomy in the treatment of obstructive sleep apnea in prepubertal children. Sleep. 2008 Jul;31(7):953-7.

22. Choi JH, Oh Jl, Kim TM, Yoon HC, Park IH, Kim THetal. Long-term subjective and objective outcomes of adenotonsillectomy in korean children with obstructive sleep apnea syndrome. Clin Exp Otorhinolaryngol. 2015 Sep;8(3):256-60. doi:10.3342/ce0.2015.8.3.256.

23. De A, Waltuch T, Gonik NJ, Famulare NN, Muzumdar H, Bent JP et al. Sleep and breathing the first night after adenotonsillectomy in obese children with obstructive sleep apnea. J Clin Sleep Med. 2017 Jun 15;13(6):805-811. doi: 10.5664/jcsm.6620.

24. Luo H, Sin S, McDonough JM, Isasi CR, Arens R, Wootton DM. Computational fluid dynamics endpoints for assessment of adenotonsillectomy outcome in obese children with obstructive sleep apnea syndrome. JBiomech. 2014 Jul 18;47(10):2498-503. doi:10.1016/j.jbiomech.2014.03.023.
25. Ding H, Wang M, Hu K, Kang J, Tang S, Lu W, Xu L. Adenotonsillectomy can decrease enuresis and sympathetic nervous activity in children with obstructive sleep apnea syndrome. J Pediatr Urol. 2017 Feb;13(1):41.e1-41.e8. doi: 10.1016/j.jpurol.2016.10.009.

26. Cassano M, Russo G, Granieri C, Ciavarella D. Modification of growth immunologic and feeding parameters in children with OSAS after adenotonsillectomy. Acta Otorhinolaryngol Ital. 2018 Apr;38(2):124-130. doi: 10.14639/0392-100X-1380.

27. Pavone M, Ullmann N, Verrillo E, Vincentiis G, Sitzia E, Cutrera R. At-home pulse oximetry in children undergoing adenotonsillectomy for obstructive sleep apnea. Eur JPediatr.2017 Apr;176(4):493-499. doi:101007/s00431-017-2868-1.

28. Maeda K, Tsuiki S, Nakata S, Suzuki K, ItohE, Inoue Y.Craniofacial contribution to residual obstructive sleep apnea after adenotonsillectomy in children: a preliminary study. J Clin Sleep Med. 2014 Sep 15;10(9):973-7. doi: 10.5664/ jcsm.4028.

29. Martinot, Jean-Benoît, Le-Dong, Nam N, Guénard, Jean-Pierre H, JeanChristian et. al. Persistent respiratory effort after adenotonsillectomy in children with sleep-disordered breathing. Laryngoscope. 2018 May;128(5): 1230-37.

30. Baumert M, Pamula Y, Martin J, Kennedy D, Ganesan A, Kabir M, et al. The effect of adenotonsillectomy for childhood sleep apnoea on cardiorespiratory control. ERJ Open Research. 2016;2(2):1-9. doi:10.1183/23120541.00003-2016.

31. Lee H, Kwon S, Lee S, Park H, Mun G, Kim M, Koo Y, Soo. The utility of adenotonsillectomy to treat snoring in children: acoustic evaluation using smartphones. Korean Journal of Otorhinolaryngology-Head and Neck Surgery. 2018 June;61(9)465-71. doi:61.10.3342/kjorl-hns.2017.01095

32. Bhat VK, Razi AM, Kumar VB. Steroid nasal spray versus curettage adenoidectomy in school children: a randomized controlled trial. J Otolaryngo ENT Res. 2018;8(5):1-6. doi:1015406/joentr.2017.08.00259

33. MartinelliEO, Haddad FLM, Stefanini R, Moreira GA, RapoportPB, Gregório LC, etal. Clinicals and upper airway characteristics in obese children with obstructive sleep apnea. Sleep Science. 2017 Jan-Mar;10(1):1-6. doi:10.5935/1984-006320170001.

34. Alonso-Álvarez ML, Cordero-Guevara JA, Terán-Santos J, Gonzalez-Martinez M, Jurado-Luque MJ,Corral-Peñafiel J et al. Obstructive sleep apnea in obese community-dwelling children: the nanos study. Sleep. 2014 May;37(5):943-9. doi:10.5665/sleep.3666.

35. Horwood L, Brouillette RT, McGregor CD, Manoukian JJ,Constantin E. Testing for pediatric obstructive sleep apnea when health care resources are rationed. JAMA Otolaryngol Head Neck Surg.2014;140(7):616-23. doi:101001/ jamaoto.2014.778

Ana de Lourdes Sá de Lira (Corresponding address)

Universidade Estadual do Piauí, Faculdade de Odontologia

Rua Senador Joaquim Pires 2076 Ininga.

CEP: 64049-590. Teresina, Piauí, Brasil

Date submitted: 2019 Jan 12

E-mail: anadelourdessl@hotmail.com 